Illinois State University

ISU ReD: Research and eData

Theses and Dissertations

$4-14-2020$

\title{
Temperament and Aggression: Examining the Link Between a Shy and Inhibited Temperament and Reactive and Proactive Aggression
}

Samantha L. Croney

Illinois State University, samantha.croney42@gmail.com

Follow this and additional works at: https://ir.library.illinoisstate.edu/etd

Part of the Developmental Psychology Commons

\section{Recommended Citation}

Croney, Samantha L., "Temperament and Aggression: Examining the Link Between a Shy and Inhibited Temperament and Reactive and Proactive Aggression" (2020). Theses and Dissertations. 1267.

https://ir.library.illinoisstate.edu/etd/1267

This Thesis is brought to you for free and open access by ISU ReD: Research and eData. It has been accepted for inclusion in Theses and Dissertations by an authorized administrator of ISU ReD: Research and eData. For more information, please contact ISUReD@ilstu.edu. 
TEMPERAMENT AND AGGRESSION: EXAMINING THE LINK BETWEEN A SHY AND

INHIBITED TEMPERAMENT AND REACTIVE AND PROACTIVE AGGRESSION

\section{SAMANTHA L. CRONEY}

\section{Pages}

Temperament dimensions of shyness and inhibitory control relate to how a child presents themselves socially in uncertain situations. Although prior research has found evidence linking temperament and aggression, little attention has been given to temperament dimensions of shyness and inhibitory control and the subtypes of aggressive behaviors. This distinction could be crucial as some children may be more likely to use aggression to interact with others due to their shy nature or may act react aggressively in situations that are unfamiliar. The goal of this study was to understand how the temperament dimensions of shyness and inhibitory control and gender are associated with reactive and proactive aggression among 4-year-old children using parent-report measures. 124 parents of 4-year-old children $(M=4.4$ years, $S D=3.22$ months; $53 \%$ female; $79.03 \%$ White) reported their child's temperament using the Short Version of the Children's Behavior Questionnaire Shyness and Inhibitory Control subscales (Rothbart, Ahadi, Hershey, \& Fisher, 2001). Additionally, parents completed the Proactive Reactive Aggression Questionnaire (Dodge \& Coie, 1987). Participants were recruited from area preschools and organizations serving children and families. Multiple ordinary least squares regression analyses were used for hypothesis testing. Model A tested whether inhibitory control, shyness, gender, and the interactions between gender and shyness and between gender and inhibitory control 
predicted reactive aggression. Specifically, it was hypothesized that low inhibitory control, high shyness, and gender (boys) would demonstrate an increase in reactive aggression with the interactions between gender and shyness and gender and inhibitory control being exploratory with no formal predictions. Model B tested whether inhibitory control, shyness, gender, and the interactions between gender and shyness and between gender and inhibitory control predicted proactive aggression. No significant effects were expected for any of the variables or interactions in Model B. As predicted, results indicated that low inhibitory control significantly predicted an increase in reactive aggression, $\beta=-2.249, t(122)=-5.567, p<.001$, yet shyness did not significantly predict an increase in reactive aggression, $\beta=.353, t(122)=.119, p=.315$, while the overall model explained a significant amount of variance, $R^{2}=.229, p<.001$. The multiple regression model for reactive aggression explained a significant amount of variance, $R^{2}=.310, p$ $<.001$. Furthermore, low inhibitory control significantly predicted an increase in proactive aggression, $\beta=-.949, t(122)=-4.087, p<.001$, whereas shyness did not significantly predict an increase in reactive aggression, $\beta=-.018, t(122)=-.011, p=.950$, These findings provide important details about links between a child's temperament and their displays of aggression. KEYWORDS: shyness, inhibitory control, aggression, temperament, proactive aggression, reactive aggression, gender 
TEMPERAMENT AND AGGRESSION: EXAMINING THE LINK BETWEEN A SHY AND

INHIBITED TEMPERAMENT AND REACTIVE AND PROACTIVE AGGRESSION

SAMANTHA L. CRONEY

A Thesis Submitted in Partial

Fulfillment of the Requirements

for the Degree of

MASTER OF SCIENCE

Department of Psychology

ILLINOIS STATE UNIVERSITY

2020 
(C) 2020 Samantha L. Croney 
TEMPERAMENT AND AGGRESSION: EXAMINING THE LINK BETWEEN A SHY AND INHIBITED TEMPERAMENT AND REACTIVE AND PROACTIVE AGGRESSION

SAMANTHA L. CRONEY

COMMITTEE MEMBERS:

Alycia Hund, Chair

Laura Finan 


\section{CONTENTS}

Page

TABLES

FIGURES

iii

CHAPTER I: INTRODUCTION

Literature Review on Temperament

Temperament and Biology

$\begin{array}{lr}\text { Gender differences in temperament } & 6\end{array}$

Aggression

Aggression and Biology

Gender differences in aggression

Temperament and Aggression

Current Study

CHAPTER II: METHOD

Participants

Measures

Aggression

Procedure

CHAPTER III: RESULTS

Hypothesis Testing 


\section{TABLES}

Table

Page

1. Frequency Distribution for Child Care Contexts

2. Frequency Distribution for Parental Education

3. Descriptive Statistics

4. Bivariate Correlations of Inhibitory Control, Shyness, Gender, Proactive Aggression, and Reactive Aggression

5. Multiple Regression Analysis for Reactive Aggression ( $\mathrm{N}=124)$

6. Multiple Regression Analysis for Proactive Aggression ( $\mathrm{N}=124)$ 


\section{FIGURES}

Figure $\quad$ Page

1. Rothbart's (1994) Theory of Temperament Model: Three Higher Order Aspects and 15 Sub-Levels 3

2. Multiple OLS Regression Analysis for Reactive Aggression 24

3. Multiple OLS Regression Analysis for Proactive Aggression 26 


\section{CHAPTER I: INTRODUCTION}

The idea of temperament was first postulated in Ancient Greece by Galen, a Greek philosopher and surgeon who developed four personality types - Choleric, Sanguine,

Phlegmatic, Melancholic_-expressed through various moods and behaviors (Howart, 1988).

More recently in the 1950's, interest in temperament as a psychological topic started to gain popularity as a possible link to understanding personality. Diamond (1957) released his animalbased research on personality and temperament, which identified four displays of temperament that both humans and social animals express: fearfulness, aggressiveness, affiliativeness, and impulsiveness. To date, temperament has been found to have some ties to aggression, yet little research has been identified how temperaments that are not classified as "difficult" relate to aggression (Goldsmith et al., 1987; Rothbart et al., 2000).

\section{Literature Review on Temperament}

Temperament is defined as "individual differences in reactivity and self-regulation" and first started to further develop the construct with the New York Longitudinal Study (Rothbart \& Derryberry, 1981). Developmental Psychologists came together in 1963 with the goal of creating a human-based experiment to understand child personality by formulating key traits and a testable scale for later research (Thomas, Chess, \& Birch, 1968; Thomas, Chess, Birch, Hertzig, \& Korn; 1963). From this research, three types of temperament were found, - easy, difficult, and slow-to-warm-up — as well as nine classifying dimensions of temperament: activity level, rhythmicity, approach/withdrawal, adaptability, sensory threshold, quality of mood, intensity of mood expression, distractibility, and persistence/attention span (Thomas \& Chess, 1986). According to this approach, individual temperament scores can be calculated as high or low ratings for each of the three main types of temperament and through high and low scores on each 
of the nine sub-dimensions. For example, a child is labeled as having a difficult temperament if they display a negative mood, high withdrawal, low adaptability, high intensity, and low regularity (Thomas et al., 1963). However, Martin, Wiesenbaker, and Huttunen (1994) conducted a factor analyses on the nine dimensions and found substantial overlap among the dimensions, that has questioned the dimensions' validity as separate variables. Their data suggests that two dimensions (i.e., threshold and biological rhythmicity) were less consistent than the more robust dimensions such as inhibitory control, negative emotionality, adaptability, activity level, and task persistence. Thus, a need for a more valid and reliable temperament measurement scale arose.

New studies and different interpretations emerged shortly after this ground-breaking work. For instance, Buss and Plowin (1975) identified emotionality, activity, sociability, and impulsivity as having a robust biological connection and that these factors are central as the foundation for identity formation. In addition, Mary Rothbart produced her own clinically verified view of temperament, focusing on individual differences in reactivity and selfregulation. Rothbart (2011) proposed three high-order aspects of temperament: Surgency, Negative Affectivity, and Effortful Control (see Figure 1). Rothbart's theory of temperament was chosen as the basis for defining temperament in the proposed study because it aligns with the constructs being studied and it had demonstrated strong empirical measurement properties (Rothbart, Ellis, Rueda, \& Posner, 2003). Specifically, Rothbart's inhibitory control has been related to shy/withdrawn behavioral displays, and Effortful Control (the higher-order aspect of temperament inhibitory control falls under) has been related to aggression in prior studies (Putnam \& Rothbart, 2006). The Child Behavior Questionnaire (CBQ) measures these aspects of 
temperament and has demonstrated strong internal consistency (Rothbart, Ahadi, Hershey, \& Fisher, 2001).

\section{Figure 1}

Rothbart's (1994) Theory of Temperament Model: Three Higher Order Aspects

and 15 Sub-Levels

\section{Rothbart Temperament}

Surgency
Extraversion
Approach: Amount of excitement and positive anticipation for
expected pleasurable activities.
High Intensity Pleasure: Amount of pleasure or enjoyment related to
situations involving high stimulus intensity, rate, complexity, novelty,
and incongruity
Activity Level: Level of gross motor activity including rate
and extent of locomotion.
Smiling \& Laughter: Amount of positive affect in response to
changes in stimulus intensity, rate, complexity, and incongruity
Shyness: Slow or inhibited approach in situations
involving novelty or uncertainty.
Impulsivity: Speed of response initiation.

\section{Negative Affectivity}

Positive and Negative Emotions

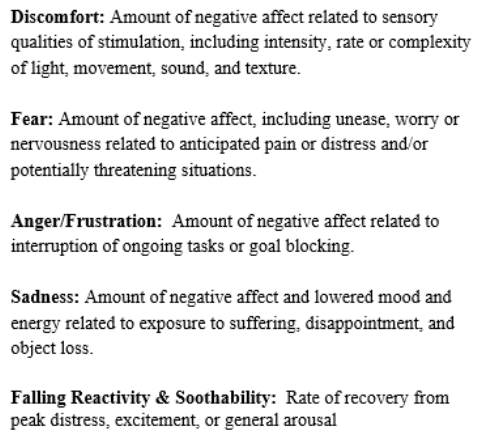

Discomfort: Amount of negative affect related to sensory qualities of stimulation, including intensity, rate or complexity of light, movement, sound, and texture.

Fear: Amount of negative affect, including unease, worry or nervousness related to anticipated pain or distress and/or potentially threatening situations.

Anger/Frustration: Amount of negative affect related to interruption of ongoing tasks or goal blocking.

Sadness: Amount of negative affect and lowered mood and energy related to exposure to suffering, disappointment, and object loss.

Falling Reactivity \& Soothability: Rate of recovery from peak distress, excitement, or general arousal

\section{Effortful Control \\ Constraint}

Surgency is reflected in behaviors such as approach, high-intensity pleasure, activity level, amount of smiling and laughter, impulsivity and shyness. Surgency is predictive of aggression (Rothbart, Ahadi, \& Hershey, 1994). Negative Affectivity was demonstrated as expressed and felt distress and behavioral and attentional aversion and has been associated with six behaviors: discomfort, fear, anger/frustration, sadness, falling reactivity, and soothability (Goldsmith et al.,1987). The third factor, Effortful Control, predicts low levels of aggression, and is defined by interactions of inhibitory control, attentional focusing, low intensity pleasure, and perceptual sensitivity demonstrated in Figure 1 above (Goldsmith et al., 1987; Rothbart et al., 1994; Rothbart, 2007; Rothbart, Ahadi, Evans. 2000; Sanson \& Rothbart, 1995). Additionally, Effortful Control develops around the second or third year of a child's life with people high in 
Effortful Control being able to regulate their behaviors through self-regulation (Rothbart et al., 2000; Rothbart, Sheese, \& Posner, 2007). Self-regulation involves voluntary control has been positively correlated to behavioral control of actions (Rothbart et al. 2000). Rothbart also demonstrated that temperament develops through emotions, or components of emotions, at different ages such that distress, avoidant movements, anger, and frustration can be seen as early as 2 to 3 months in infants (Rothbart, 2007; Rothbart et al., 2000; Sanson, Hemphill, \& Smart, 2004).

As noted above, Rothbart's CBQ was chosen for this study due to the reliability and validity of the CBQ compared to other measures of temperament, as well as a large body of research connecting the CBQ to behaviors including aggression. The current study focused on two subscales of temperament from the CBQ: shyness and inhibitory control. Shyness has been defined as slow, avoidant, or inhibited approaches to novel situations or uncertainty (Rothbart, Ahadi, \& Hershey, 1994). Theall-Honey and Schmidt (2006) reported that girls demonstrate more shyness than boys. Although by this definition shyness is associated with inhibition, Reznick et al. (1986) have demonstrated that children who are behaviorally inhibited are not always classified as shy. Shyness is associated with other temperament dimensions such as low self-regulation, low positive affect, high negative emotionality, and high emotion reactivity (Eisenberg, Fabes, \&Murphy, 1995).

Inhibitory control has been found to be correlated with aggression and is related to shyness on a definitional basis with inhibitory control initially being displayed like shyness. Inhibitory control has been defined by Rothbart (1994) as "the capacity to plan and suppress inappropriate approach responses under instructions or in novel or uncertain situations" (p. 29). Gender differences in inhibitory control have indicated moderate differences with girls 
demonstrating more inhibitory control than boys (Else-Quest et al., 2006). On a definitional basis alone, suppressing inappropriate actions, gives the illusion of good regulatory skills that might help to reduce aggression. As will be discussed later, low levels of inhibitory control have been linked with higher aggression (Kochanska, 2000). The difference between shyness and inhibitory control is that inhibitory control is more of a temporary shyness to a novel situation, whereas shyness is general to all aspects of life, not just new situations.

\section{Temperament and Biology}

With the various interpretations of temperament, definitions vary, yet the aspects of temperament for which most researchers agree on are the biological relation of behavior to genetics, and the idea that temperament interacts with the environment throughout one's life (Dadds \& Salmon, 2003; Rothbart et al., 2007). Recent research has focused on the connection between temperament, aggression, and brain function (Dadds \& Salmon, 2003; Dane \& Marini,

2013; Dodge \& Coie, 1987; Dodge et al., 1997; Hubbard, McAuliffe, Morrow, \& Romano, 2010; Kochanska, Murray, \& Harlan, 2000; Matthies et al. 2012; Poulin \& Boivin, 2000; Tremblay et al., 2004). With growing knowledge of genetics and phenotypes, a new theory of temperament has emerged through behavioral genetic research (Comings et al., 2001). Theories that focus on the behavioral genetic study of temperament primarily have focused on one dimension of temperament and, through twin studies and isolating interested genes, researchers have been able to link certain aspects of temperament to regions of the brain. The brain areas that have received the most research attention are the nucleus accumbens and the hypothalamus (Rettew, 2013).

Additionally, Coplan and Armer (2007) reported that extremely shy children may have a lower threshold for arousal in the central nucleus of the amygdala. This arousal pattern might be explained by their shy nature influencing an "increased heart rate acceleration to mild stress, 
higher early morning levels of salivary cortisol, and patterns of electroencephalogram (EEG) responses characterized by greater right frontal activation" (pp. 27). Schwartz et al. (2003) demonstrated that inhibited children had higher activation in both the left and right area of the amygdala during novel situations. Fox and Davidson (1988) also suggested that higher levels of brain activity on the left side is linked to undesirable effects such as fear and sadness and withdrawal tendencies, whereas right brain activity relates to positive emotions and one's approachability. These examples of biologically based studies that link regions of the brain with temperament provide further insight into why children display behaviors differently. Although the current study will not address the biological basis of temperament, these studies inform behavioral research on temperament.

Gender differences in temperament. In the United States there are different gender norms and expectations for males and females, one would expect to find established gender differences in temperament due to environmental influences. Yet the current literature review found no gender differences in children have been found in past studies focusing on shyness. Doey et al. (2014) hypothesized that gender differences might be observed later in late childhood/early adolescence if social anxiety disorders develop. Consistent with this notion, adolescent girls are more socially anxious than males, and adult women are 1.5 to 2 times more likely than men to be diagnosed with social anxiety disorder (Doey et al., 2014; Kendall et al., 2006; Kessler et al., 2005).

Furthermore, there may be gender differences in the socially acceptable nature of shyness. For example, Coplan, Findlay, and Nelson (2004) found that 3- to 6-year-old girls' shy and anxious behaviors were accepted and even rewarded by parents, whereas boys of the same age were more likely to receive more negative interactions to these behaviors. Societal 
acceptance and praise of girls' shy behaviors may reduce girls' feelings of emotional distress since they are acting in a way that is deemed "more acceptable" in their environments. In contrast, boys may experience distress due to the disconnect between boys' shy behaviors and societal expectations that boys should express more outspoken behaviors (Doey et al. 2014). Furthermore, gender difference in temperament have also been observed through inhibitory control. Kochanska et al. (1996) found gender differences in inhibitory control and impulsivity during toddlerhood. Girls outperformed boys on both tasks with girls rating higher on inhibitory control and lower on impulsivity than the boys. This finding provides further evidence of possible gender distinctions between temperaments.

\section{Aggression}

Aggression is an internal, stable, personality-like trait (Parke \& Slaby, 1983). In preschoolers, it is displayed through a variety of behaviors including temper tantrums, bullying, teasing, name-calling, coercive acts, and domination (Dodge et al., 1997). Aggressive behavior patterns are consistent across settings and stable across time (Dadds \& Salmon, 2003). Over half of all aggressive behavior is displayed by just 10\% of boys (Dodge, Coie, Pettit, \& Price, 1990; Olweus, 1981). Aggression has also shown to be related to antisocial behaviors and internalizing problems (Loeber \& Dishion, 1983). With two forms of aggression (i.e., proactive and reactive aggression) being distinguished by variations in social behaviors such as how one perceives social cues (Crick \& Dodge, 1996). This study looked specifically at 4-year-olds since $72 \%$ of all preschool aged children show some form of aggression and young children learn to inhibit physical aggression during the preschool years (Schwartz et al., 1998). This demonstrates a need for aggression interventions in the preschool setting since children receive the most behavior 
interventions in preschool and receive more academic and less behavioral interventions the older, they get (McClowry et al., 2013).

As Dodge et al. (1997) noted, “'Reactive aggression includes anger expressions, temper tantrums, and vengeful hostility, and proactive aggression includes bullying, domination, teasing, name-calling, and coercive acts" (pp. 38). Proactive aggression was defined as "aggression as a product of high self-efficacy for aggression, favorable outcomes from aggression, and valuing outcomes that are obtained through aggressive means" (Card \& Little, 2006). This study focused on proactive and reactive aggression because $77 \%$ of children score either high or low for both types (Dodge \& Coie, 1987).

Reactive aggression has been linked to the hostile attributional bias (Hubbard et al., 2010), which states that when exposed to a frustrating stimulus, individuals will interpret the stimulus as an aggressive cue and therefore respond aggressively (Dodge \& Frame, 1982). The hostile attribution bias may explain the link between temperament and reactive aggression. A child who automatically reacts aggressively in a situation demonstrates impulsivity and low inhibitory control given they cannot calm themselves down and reason through the situation before reacting aggressively. Essentially, reactive aggression is present when someone interprets a stimulus as aggressive and therefore reacts aggressively towards that stimulus. A person's primary goal in using reactive aggression is to react to the stimulus and "hurt the perpetrator of provocation or the threat" (Vitaro \& Brendgen, 2005). Proactive aggression, on the other hand, is deliberate, aggressive behavior that comes from goal-directed behavior to use aggression to achieve a goal (Polman et al., 2007).

Additionally, reactive aggression is impulsive and immediate as compared to proactive aggression which can be planned out. Reactive aggression is seen as a poor adjustment to novel 
stimuli and places, which heavily relates to dimensions of temperament such as low Effortful Control, Negative Affect, and low fearfulness (Dane \& Marini, 2014; Hubbard et al., 2010; Tremblay et al., 2004). A critical distinction between reactive and proactive aggression is the age of onset. Dodge et al. (1997) followed kindergartners for four years and compared reactive and proactive aggression. Based on both teacher and peer reports, "general behavior problems of reactively aggressive children had an earlier age of onset than those for proactively aggressive children" ( $\mathrm{p} 44)$. This distinction could have resulted in this study observing more reactively aggressive children since the current studies sample is younger than the elementary school sample included in the work by Dodge and colleagues.

Proactive aggression, on the other hand, is seen as an outcome of Bandura's (1973) social learning model of aggression which suggests that aggression is acquired behavior that is governed by reinforcements. Positive outcomes that one receives from using aggression (e.g., stealing a toy by using aggression) further promotes self-efficacy for these aggressive behaviors (Polman, Castro, Koops, Boxtel, \& Merk, 2007). Children who demonstrate proactive aggression have been shown to anticipate positive outcome expectancies of aggression (Hubbard et al., 2010). Additionally, proactive aggression is positively associated with antisocial behaviors, alcohol use, and indicators for psychopathic personalities among xxx aged individuals (Dodge et al., 1997; Raine et al., 2006). The major difference between reactive and proactive aggression is how they are internalized. For instance, reactive aggression relates to internalizing problems due to the struggle one faces internally when interpreting vague stimuli, they perceive as aggression. Proactive aggression, on the other hand, is displayed in a more external way demonstrated by the positive outcomes one expects to receive from acting aggressively. Along with social withdrawal, aggression is related to various poor developmental outcomes. 
A meta-analysis conducted by Card and Little (2006) compared proactive and reactive aggression results from past studies with children aged 5-13, to test for associations with six indices of maladjustment (internalizing problems, emotional dysregulation and attentiondeficit/hyperactivity disorder symptoms, sociometric status, prosocial behaviors, peer victimization, and delinquent behaviors). They found that reactive aggression was independently related to all six indices of maladjustment with the strongest relation to internalizing behaviors. This is an important distinction because reactive aggression has been linked with emotional dysregulation and attention-deficit/hyperactivity disorder which strongly relates to dimensions of temperament such as impulsivity and attentional problems (Card \& Little, 2006).

Differences in social outcomes for reactively aggressive individuals tend to be more negative than for proactive individuals. The most descriptive of these differences is reactive aggressive individuals tend to experience peer rejection and victimization, whereas proactively aggressive individuals gain popularity from their use of aggression in specific school settings (Chang et al, 2005; Dodge \& Coie, 1987; Hubbard et al., 2010; Poulin \& Boivin, 2005). These differences are visible at different developmental levels, with Dodge and Coie's (1987) study finding that in a sample of third through sixth grade children, proactively aggressive boys are seen as leaders, and Chang et al.'s (2005) study finding the same effect but in a sample of adolescents. Furthermore, reactive and proactive aggression can easily be distinguished by their use of verbal aggression (Chang et al., 2005), since reactive aggression has been associated with only physical aggression and proactive aggression relies on more verbal forms of aggression to gain rewards (Poulin \& Boivin, 2000). Furthermore, reactive aggression was related to significantly worse social preference and children who demonstrated high reactive aggression were 3.5 to 4 times more likely to be rejected than proactive peers (Dodge et al., 1997). These 
links from proactive and reactive aggression to maladjustment suggest that mitigating these adverse effects early on could later protect children with specific temperaments from the harmful future associations with peer rejection and victimization.

\section{Aggression and Biology}

The amygdala has been strongly linked to aggression, motor activity, reactivity, and inhibitory control, with low amygdala activity specifically being associated with high levels of inhibitory control (Dadds \& Salmon, 2003; Kagan, 1998; Kagan \& Snidman, 1999; Matthies et al., 2012; Schwartz et al. 2003). Matthies et al. (2012) found that women with higher scores on the Life History of Aggression Assessment had 16-18\% smaller amygdala volumes. Additionally, Lesch and Merschendorf (2000) found that 5HT system (which diffuses serotonin) was a modulator for social behaviors such as impulsivity in the form of aggression and anxiety. Furthermore, individuals who carry the short allele of the serotonin transporter 5HTT, displayed higher reactivity and inhibitory control. They also found that a higher frequency of the HTR1B$861 \mathrm{C}$ allele is associated with antisocial behavior and aggression as well as high-aggressive individuals demonstrating higher 5HT1A mRNA in the hippocampus. The work done by Lesch and Merschendorf (2000) as well as Matthies et al. (2012) provides a map of the focal brain regions involved in aggression but also strongly connects these specific brain areas with social behavior.

Gender differences in aggression. Child gender has been linked to many notable differences in the display of aggression (Lesch \& Merschdorf, 2000; Thomas et al., 2011; Tremblay et al., 2004). Thomas et al. (2011) found gender differences in aggression expression specifically in an elementary classroom setting such that boys displayed higher rates of all aggression than girls. Furthermore, boys have been characterized as demonstrating more physical 
aggression as compared to girls (Moffitt, Caspi, Rutter, \& Silva, 2002; Tremblay et al., 2004).

Crick and Grotpeter (1995) established that elementary-school aged girls are more likely to display relational aggression (i.e., causing harm to someone's relationships or social status).

Interestingly, Connor et al. (2003) found that there are no gender differences between proactive and reactive aggression in children and adolescents. Their study included 323 five- to eighteenyear-olds. Reactive and proactive aggression were assessed using the Reactive Proactive Aggression Questionnaire which will also be used in this study. There was no significant difference between boys and girls for either type of aggression, yet $79 \%$ of their sample size identified as male, so further research may be needed.

In contrast, Hay et al. (2011) found that girls demonstrate more reactive aggression than boys. Four waves of participants at different ages participated in the study. The first sample was comprised of 60 infants at 11 months. The second sample consisted of 48 children with a mean age of 11.9 months. The last two samples were made up of toddlers with 54 toddlers starting at 18 months of age in the third sample, and 60 children with a mean age of 28 months in the fourth sample. They found that in infancy, girls initially used bodily force (defined as reactive aggression) more than boys in response to peers whereas the toddler age group boys were significantly more likely to use bodily force in reaction to peers than girls were. Additionally, they found that boys and girls use verbal skills in conflict and do not always react physically. Findings from these two studies are contradictory and call for further investigation into possible gender differences in reactive and proactive aggression.

\section{Temperament and Aggression}

Though most temperament psychologists discourage labeling certain children as having "difficult" temperaments, research focused on aggression has shown some connection to 
temperament through impulsivity, hyperactivity, lack of empathy, and fearlessness (Brendgen, Vitaro, Tremblay, Lavoie, 2001; Dane \& Marini, 2014; Dodge, Lochman, Harnish, Bates, \& Pettit, 1997; Goldsmith et al., 1987; Tremblay et al., 2004). The higher order temperament construct that includes inhibitory control— have been related to aggression numerous times (Dadds \& Salmon, 2003; Kochanska, 2000; Rothbart et al., 1994, 2000). Rothbart et al. (2000) found an association between deficits in Effortful Control and aggressive behaviors in 4 and 5year-old children. Similarly, Kochanska (2000) demonstrated that Effortful Control predicted children's emotion regulation. Furthermore, Murray and Kochanska (2002) found that lower levels of Effortful Control were associated with externalizing behaviors such as physical aggression. These findings further cement the idea that Effortful Control is the primary strategy used to regulate inappropriate aggressive responses.

In addition to Effortful Control, temperament dimensions such as high negative emotionality, high impulsivity, and low inhibitory control also have been related to aggression. Higher levels of impulsivity have been related to higher levels of physical aggression among college students (Hatfield \& Dula, 2014). Links between temperament and aggression have also been found with regard to overlapping areas of brain activation. Specifically, the amygdala has been associated with shyness and inhibitory control as well as aggression. Inhibitory control in novel situations is associated with higher activation of the amygdala and the volume and size of the amygdala have been associated with aggression (Coplan \& Armer, 2007; Schwartz et al. 2003). For example, Matthies et al. (2012) found that smaller amygdalae were associated with higher aggression.

Kimonis et al. (2006) examined the relation between antisocial and aggressive behaviors in young children and found a connection between low activation in the amygdala, and 
associated with high inhibitory control, and proactive aggression (Lozier et al., 2014). Yet a study conducted by Lozier at al.'s (2014) found that adolescents with high proactive aggression showed lower amygdala blood oxygenation response to the faces of distress (a demonstration of low inhibitory control in this study), providing evidence that proactive aggression is related to empathy deficits (Blair, 2005) as well as reduced activation in the amygdala, which is indicative of high inhibitory control and is opposite of past findings connecting low inhibitory control with high amygdala activation.

\section{Current Study}

The transition from preschool to elementary school involves many developmental changes and adjustments for children. Many children enroll in elementary school as early as 5 years old and must learn how to acclimate their behavior to the structure of all-day instruction. Thus, interventions should focus on targeting children at 4 years old to better help them transition successfully to elementary school. Although past research has demonstrated a relation between temperament traits and aggression, no studies have examined links between shyness and inhibitory control in relation to aggression, especially reactive and proactive aggression. In the current study, shyness and inhibitory control were measured using the CBQ completed by parents of 4-year-old children. Additionally, reactive and proactive aggression were measured using parent reports on the Reactive- Proactive Aggression Questionnaire (RPQ).

The main goal of this study was to find differential predictive relations for shyness, inhibitory control, and gender with reactive and proactive aggression among young children. The first model focused on the following research question: Do the temperament elements of low inhibitory control and high shyness predict reactive aggression? I predicted that children who scored higher on the shyness subscale would score higher in reactive aggression because reactive 
aggression is automatically responding in an aggressive manner to a perceived threat (Vitaro \& Brendgen, 2005). Additionally, since inhibitory control has been related to aggression as a part of Effortful Control in prior studies, I predicted the current study would find a similar connection between low inhibitory control and high reactive aggression (Matthies et al., 2012; Putnam \& Rothbart, 2006; Rimm-Kaufman \& Kagan, 2007). Finally, I predicted that gender would predict reactive aggression, with boys displaying higher rates of reactive aggression. Since boys display more physical aggression than girls, and reactive aggression is more physical, I predicted there would be a gender difference for reactive aggression (Moffitt, Caspi, Rutter, \& Silva, 2002; Tremblay et al., 2004). To provide more information on gender and inhibitory control, I examined the interaction between gender and inhibitory control since prior research has found moderate gender effects favoring girls (Else-Quest, 2006). The interaction between gender and shyness was also examined since prior research reported that girls demonstrated shyness more than boys (Theall-Honey \& Schmidt, 2006). Though past research has demonstrated that girls are more likely to display shyness or inhibitory control, the present study aimed to provide more distinct information as to how gender might affect how one might use aggression, especially since gender differences for proactively aggressive boys reveals higher social status.

The second model focused on proactive aggression specifically: Do the temperament dimensions of inhibitory control and shyness predict proactive aggression? Though past behavioral literature has connected Effortful Control with aggression, most of the studies finding this connection have defined aggression as "physical aggression" (Kochanska, 2002). Therefore, I predicted that inhibitory control would not be predictive of proactive aggression. Furthermore, shyness has not been found to connect to aspects of proactive aggression through the literature review, so I did not predict shyness to connect to proactive aggression. Additionally, the 
literature review on gender predicting aggression has been mixed. Girls have been found to use more verbal skills when in conflict, so they may be less likely to automatically act aggressively (Crick \& Grotpeter, 1995). Due to these mixed findings, it was unclear whether gender was predictive of proactive aggression and remained an exploratory question. Interactions of gender with inhibitory control and shyness were tested on an exploratory basis. 


\section{CHAPTER II: METHOD}

\section{Participants}

I recruited 124 parents of 4 -year-old children $(M=4.4$ years, $S D=3.22$ months $)$. An $a$ priori calculation of power using $\mathrm{G}$ prime indicated that 120 participants would be needed to test the main aspects of my hypotheses. Parent reports indicated that $47 \%$ of the children identified as male and 53\% identified as female. Parents/guardians provided consent for their participation by completing the measures. Once participants completed the survey, they were given the option to submit their contact information on another page to be entered into a drawing for 1 of $5 \$ 10$ Amazon gift cards.

\section{Measures}

Parents completed a demographic form where they answered questions about their child's gender identity, race and ethnicity, state of residence, parental education, and type of childcare (i.e., morning day-care, afternoon-daycare, babysitter/nanny, parent or family, full time preschool). Descriptive information for the child's childcare arrangements and parental education levels are displayed below in Table 1 and Table 2, respectively. From the information collected, $79.03 \%$ of the children were identified as White, $8.06 \%$ identified as Asian, $6.45 \%$ identified as Other, $4.84 \%$ as Black or African American, .81\% identified as American Indian or Alaska Native, and .81\% did not report. 
Table 1

Frequency Distribution for Child Care Contexts

\begin{tabular}{lcc}
\hline \multicolumn{1}{c}{ Variable } & $\mathrm{N}$ & $\%$ \\
\hline Child Care Center & 29 & $23.39 \%$ \\
Family Care & 13 & $10.48 \%$ \\
Pre-school/Kindergarten prep & 47 & $37.90 \%$ \\
Before/After School Care & 0 & --- \\
Nanny/Babysitter & 8 & $6.45 \%$ \\
Occasional, Flexible, or Casual Care & 1 & $.81 \%$ \\
Other & 29 & $23.39 \%$ \\
Unreported & 1 & $.81 \%$
\end{tabular}

Table 2

Frequency Distribution for Parental Education

$\begin{array}{lll}\text { Variable } & \mathrm{N} & \%\end{array}$

Less than high school

High school graduate

Some college

2-year degree

6

$4.84 \%$

4-year degree

52

$41.93 \%$

(Table Continues) 
Table 2, Continued

\begin{tabular}{ccc}
\hline Variable & $\mathrm{N}$ & $\%$ \\
\hline Professional degree & 32 & $25.81 \%$ \\
Doctorate & 13 & $10.48 \%$ \\
\hline
\end{tabular}

Note. $N=124$

\section{Temperament}

Parents completed the Shyness and Inhibitory Control subscales of the Short Version of the Children's Behavior Questionnaire (Rothbart et al., 2001). In general, the CBQ is used for assessing temperament among children between the ages of 3 and 8 years and has 15 subscales. The CBQ has demonstrated adequate internal consistency and is highly reliable even across cultures (Rothbart et al., 2001). For instance, Cronbach's alpha for the short version of the shyness subscale is .85 and .72 for the inhibitory control subscale (Rothbart, Ahadi, Hershey, \& Fisher, 2001). Parents read items and rated their children's reactions within the past six months on a Likert Scale ranging from 1 to 7: extremely untrue of your child (1), quite untrue of your child (2), slightly untrue (3), neither true nor false (4), slightly true (5), quite true (6), extremely untrue of your child (7). Parents had the option to mark "not applicable" if they have not observed their child in the situation described. Subscale scores for the short form represent the mean score of all subscale items and are computed by reverse coding one item from each subscale and then summing all numerical responsive and diving by total number of items for which a numerical rating was provided to determine the subscale score.

Shyness was measured using the Shyness subscale. This scale included 6 items such as "Is sometimes shy even around people s/he has known a long time". The Cronbach's alpha for my sample was .825 , representing adequate internal consistency. 
Inhibitory Control was measured using the Inhibitory Control subscale. The 6 questions include items such as "Can wait before entering into new activities if s/he is asked to" and "Can easily stop an activity when s/he is told is told "no". The Cronbach's alpha for my sample was .729 , representing adequate internal consistency.

\section{Aggression}

Parents also completed 19-items out of 23-items on the Reactive-Proactive Aggression Questionnaire (RPQ) that yields reactive and proactive subscales (Dodge \& Coie, 1987). Of the 23 original statements, four were removed since they did not reflect our age group well: "had a gang fight to be cool", "vandalized something for fun", "made obscene phone calls for fun", and "carried a weapon to use in a fight", leaving eleven reactive statements, such as "my child reacts angrily when provoked by others", and eight proactive statements, such as "my child often takes things from others".

Parents indicated how often their child exhibited the behaviors described by the items by marking 0 (never) 1(sometimes) or 2 (often). In the original study, Cronbach's alpha for the reactive scale was 0.84 , with the proactive aggression scale equaling 0.86 , and total aggression demonstrating 0.90 (Dodge \& Coie, 1987). The RPQ has been found to be reliable and valid for assessing aggression (Raine et al., 2006). Scores are expressed on a continuum for each subscale and overall. Answers for proactive aggression (Items 2, 4, 10, 12, 15, 17, 20, 23) and reactive aggression (Items 1, 3, 5, 7, 8, 11, 13, 14, 16, 19, 22) were added together to form a summed score of proactive and reactive subscales. The Cronbach alpha for reactive aggression for my sample was .844 , with proactive equaling .713, demonstrating adequate internal consistency. The lower Cronbach alpha for proactive aggression may reflect the smaller number of items after the removal of the questions described above. 


\section{Procedure}

After IRB approval (IRB-2019-342) and site permissions were obtained, parents were invited to participate. Participants were given the option to participate online or via a paper copy of the survey. The vast majority of our participants $(96 \%)$ responded via paper copy. Participants were invited to participate in the study in a variety of ways, including Facebook postings, parent email lists, posters and flyers at family-friendly locations (e.g., local libraries and museums, places where families gather), and through local parent-babysitter groups, park and recreation programs, gyms, aquatic centers, and childcare centers. Locations of participants was limited to the United States. Materials were provided online via Qualtrics, or paper version of the packet were created with an envelope for easy returns. 


\section{CHAPTER III: RESULTS}

The current study utilized OLS multiple regression to examine the predictive relationship of shyness, inhibitory control, gender, the interaction between gender and shyness, and the interaction between gender and inhibitory control to predict reactive aggression and proactive aggression. The analyses involving the interactions were exploratory in nature. Table 3 below depicts the descriptive statistics for the variables of interest. The table shows that overall, reactive aggression scores were higher $(M=8.81, S D=3.95)$ than proactive aggression scores $(M=2.66, S D=2.13)$. Table 4 below depicts a correlation matrix for the variables of interest. The table demonstrates a significant negative correlation between inhibitory control and proactive aggression, $r(122)=-.45, p<.001$, demonstrating that proactive aggression declines as inhibitory control increases, or vice versa. Additionally, reactive aggression was significantly correlated with inhibitory control and proactive aggression. Once again, inhibitory control was negatively correlated with reactive aggression, $r(122)=-.55, p<.01$, demonstrating that reactive aggression declines as inhibitory control increases. Reactive and proactive aggression were significantly positively correlated, $r(122)=.61, p<.01$. Shyness and Inhibitory Control were not correlated possibly due to a difference in classification of Rothbart's higher orders of temperament. Overall, the current study found that inhibitory control was related to both reactive and proactive aggression in a younger sample than prior studies. 
Table 3

Descriptive Statistics

\begin{tabular}{lcccc}
\hline \multicolumn{1}{c}{ Variable } & Min & Max & Mean & SD \\
\hline 1. Inhibitory Control & 1.67 & 7.00 & 5.01 & 1.07 \\
2. Shyness & 1.00 & 6.50 & 4.00 & 1.33 \\
3. Child Age & 4.00 & 4.88 & 4.4 & 3.22 \\
4. Reactive Aggression & .00 & 19.00 & 8.81 & 3.95 \\
5. Proactive Aggression & .00 & 11.00 & 2.66 & 2.13 \\
6. Total Aggression & .00 & 27.00 & 11.48 & 1.33 \\
\hline
\end{tabular}

Note $n=124$

Table 4

Bivariate Correlations of Inhibitory Control, Shyness, Gender, Proactive Aggression, and Reactive Aggression

\begin{tabular}{|c|c|c|c|c|}
\hline Variable & 1 & 2 & 3 & 4 \\
\hline 1. Inhibitory Control & --- & & & \\
\hline 2. Shyness & -.03 & --- & & \\
\hline 3. Gender & .13 & .06 & --- & \\
\hline 4. Proactive & $-.41 * *$ & -.02 & -.03 & --- \\
\hline 5. Reactive & $-.55 * *$ & .05 & -.11 & $.61 * *$ \\
\hline
\end{tabular}




\section{Hypothesis Testing}

The first research question focused on the extent to which shyness and inhibitory control (temperament factors) and gender predict reactive aggression. This was tested using a regression model with inhibitory control, shyness, gender, the interaction between gender and inhibitory control, and the interaction between gender and shyness predicting reactive aggression. The multiple regression model for reactive aggression with all five predictors explained a significant amount of variance, $R^{2}=.310, p<.001$. The results are depicted below in Figure 2 and Table 5, showing that inhibitory control scores significantly predicted reactive aggression, such that lower inhibitory control was associated with higher reactive aggression. These findings provide support for my hypothesis that low inhibitory control would predict reactive aggression.

\section{Figure 2}

Multiple OLS Regression Analysis for Reactive Aggression

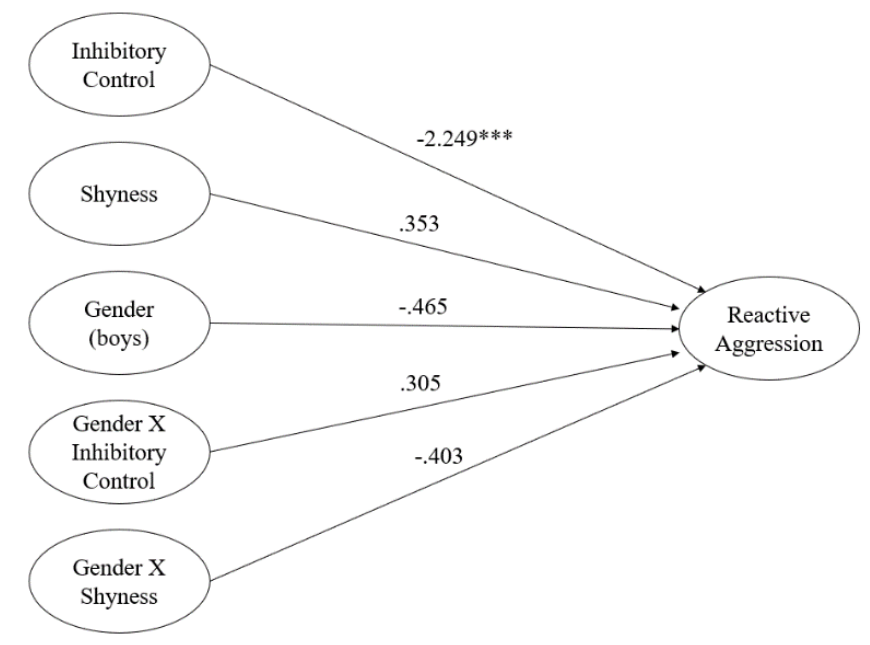

Note. ${ }^{* * *} p<.001$, standardized regression coefficient $=\beta$ 
Table 5

Multiple Regression Analysis for Reactive Aggression (N=124)

\begin{tabular}{lccc}
\multicolumn{1}{c}{ Variable } & $\mathrm{B}$ & $\mathrm{SE}$ & $\beta$ \\
\hline 1. Inhibitory Control Scores & -2.249 & .404 & $-.576^{* * *}$ \\
2. Shyness Scores & .353 & .334 & .119 \\
3. Gender (male =1) & -.465 & 3.513 & -.064 \\
4. Gender X Inhibitory Control & .305 & .621 & .224 \\
5. Gender X Shyness & -.403 & .396 & -.237 \\
\end{tabular}

Note. ${ }^{* * *} p<.001, R^{2}=.310$

The second research question focused on the extent to which inhibitory control, shyness, and gender predict proactive aggression. This was tested using a regression model with inhibitory control, shyness, gender, the interaction between gender and inhibitory control, and the interaction between gender and shyness as predictors. The multiple regression model for proactive aggression with all five predictors explained a significant amount of variance, $R^{2}=.229, p<.001$. The results are depicted below in Figure 3 and Table 6, showing that inhibitory control scores significantly predicted proactive aggression, such that lower inhibitory control was associated with higher proactive aggression. 


\section{Figure 3}

\section{Multiple OLS Regression Analysis for Proactive Aggression}

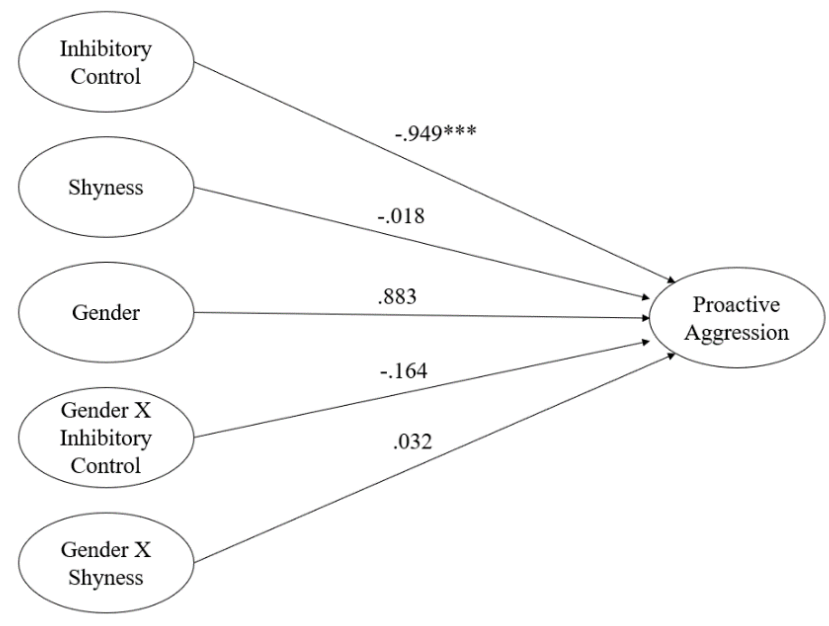

Note. ${ }^{* * *} p<.001$, standardized regression coefficient $=\beta$

Table 6

Multiple Regression Analysis for Proactive Aggression $(N=124)$

\begin{tabular}{lccc}
\multicolumn{1}{c}{ Variable } & $\mathrm{B}$ & $\mathrm{SE}$ & $\beta$ \\
\hline 1. Inhibitory Control Scores & -.949 & .232 & $-.447 * * *$ \\
2. Shyness Scores & -.018 & .192 & -.011 \\
3. Gender (male =1) & .883 & 2.019 & .225 \\
4. Gender X Inhibitory Control & -.164 & .357 & -.222 \\
5. Gender X Shyness & .032 & .227 & .034
\end{tabular}

Note. ${ }^{* * *} p<.001, R^{2}=.229$ 


\section{CHAPTER IV: DISCUSSION}

This study's findings demonstrate the extent to which inhibitory control and shyness, two elements of temperament, predict two forms of aggression: reactive and proactive. Although no significant results were found between shyness and aggression, inhibitory control negatively predicted both reactive and proactive aggression in this study. These findings provide crucial insight regarding the relation between inhibitory control and aggression, as well as having implications for families and childcare centers.

My findings clearly indicate that inhibitory control is related to aggression such that lower inhibitory control scores predict higher levels of reactive and proactive aggression among 4-year-old children. The current study was composed of a fair number of aggressive children (58.06\% scored high in total aggression) with the majority of children scoring higher in reactive aggression than proactive aggression. Additionally, children in the current study were reported low in inhibitory control $(54.84 \%)$ more than they were high in shyness $(30.65 \%)$. In temperament, the self-regulatory aspect (including inhibitory control) has been shown to be a strong link to many facets of socialization. For example, Effortful Control, which regulates behaviors through self-regulation and includes the dimension of inhibitory control in Rothbart's model, has been linked to lower levels of aggression (Rothbart et al., 2000; Rothbart, Sheese, \& Posner, 2007). Additionally, inhibitory control, unlike shyness, has already been linked to aggression via clinical assessments (Driscoll, Zinkivskay, Evans, \& Campbell, 2010; Kimonis et al. 2006). My results expand these findings by showing that inhibitory control is related to both reactive and proactive aggression. Even though prior studies have revealed mixed results with regard to the relationship between reactive and proactive aggression, the relationship between

low inhibitory control and reactive and proactive aggression could be due to the high correlation 
between the two types of aggression or the fact that the current study utilized questionnaires instead of clinical assessments of aggression and temperament. Key aspects associated with inhibitory control that might explain the relationship between inhibitory control and aggression are executive function and emotion regulation in preschool children (Carlson \& Wang, 2007; Raaijmakers et al., 2008). Both executive function and emotion regulation involve self-regulation to process emotions, thoughts, and actions (Séguin \& Zelazo, 2005). Children with deficits in executive function show an increase in impulsivity and a loss of self-control (Driscoll et al., 2010; Raaijmakers et al., 2008). Moreover, children who can effectively use attention to regulate behavior are better able to inhibit aggressive responses. These findings support the idea that inhibitory control is involved in behaviors, including modulating potentially aggressive responses.

During the preschool years, inhibitory control is still developing, as it is only initially presented at the end of the first year of life (Rothbart, Ahadi, \& Evans, 2000). This means, at 4 years, the children described by our sample had not had long to practice and refine their inhibitory control skills. As such, it is not uncommon for young children to display relatively high levels of aggression due to the underdevelopment of their inhibitory control. Tremblay et al. (2004) reported a majority of children at 17 months of age demonstrate physical aggression towards siblings, peers, and adults. Without proper self-regulation practice, a child might be more inclined to give into an aggressive act. This could account for why $72 \%$ of children at 3.5 years show some form of aggression (Tremblay et al., 2004).

At 4 years, many children (in the United States context) are preparing for the transition from preschool into elementary school. In our sample, $60.2 \%$ of the children were in preschool or some form of childcare kindergarten preparation program. The other $40 \%$ of the children in 
our sample reported being in family or nanny/babysitters care. As described above, $72 \%$ of all preschool-aged children demonstrate some form of aggression, and at the preschool level, teachers may spend more time addressing these problem behaviors (Tremblay et al., 2004). This demonstrates how critical behavioral interventions are before children enter elementary school. The transition to elementary school poses new challenges where children must become accustomed to new students, teachers, rules, and even a new school. Children with low inhibitory control might have an increasingly hard time with this transition.

A critical distinction between reactive and proactive aggression is the age of onset. Dodge et al. (1997) followed kindergartners for four years and compared reactive and proactive aggression. Based on both teacher and peer reports, "general behavior problems of reactively aggressive children had an earlier age of onset than those for proactively aggressive children" (p. 44). From this study, I expected to find more reactively aggressive children in our sample since they were younger than kindergarten. Interestingly, the current study found both reactive and proactive aggression in a younger sample. This distinction could come from a difference in RPQ versions ( 3 items vs. 19 items) or from other aspects of the self-report design.

Furthermore, many past studies have noted gender differences in aggression (Driscoll et al., 2010; Kimonis et al., 2006; Lozier at al., 2014; Tremblay et al., 2004). Yet, the current study did not find any significant gender differences in aggression. As stated earlier, inhibitory control only begins to emerge at the end of the first year of life. With our sample having little practice with inhibitory control, and $54.84 \%$ of our sample displaying low inhibitory control, it could be hypothesized that this age of decreased inhibitory control could result in, overall, more reporting of aggression. Since these children are still learning how to use inhibitory control, this age period may signify a time of relatively high aggression as children learn how to inhibit thoughts, 
emotions and actions. This could explain why our study did not find any gender differences, as they might not have a fully developed sense of inhibitory control in order to find significant differences.

As demonstrated by the present data, children with low inhibitory control are significantly more likely to display reactive and proactive aggression. A child that simply becomes overwhelmed from the new transition might not have the skills needed to reduce their aggression when encountering this new situation. Teachers and children alike can benefit from increased self-regulation interventions at 4-years-old or before the transition to elementary school in order to cope better with the new school, drawing on inhibitory control to help reduce aggression that might follow.

The present findings can provide teachers and parents alike with a better understanding as to how new situations can impact inhibitory control, which can lead to increases in aggression. Teachers and caregivers can use knowledge about children's temperament to help their child learn how best to control their aggression and express themselves in more appropriate ways. A reported component of inhibitory control, self-control, has been linked to better regulation practices by reducing aggression (Denson, DeWall, \& Finkel, 2012). Thus, the data collected here suggests control comes from better, or higher inhibitory control. Interventions focused on increasing self-control and regulation can in turn increase inhibitory control which could help to lower aggression. This could be demonstrated by teacher's increasing self-control skills such as providing calming techniques for aggression or by practicing inhibitory control by providing techniques for young children to use when trying not to do something they should not be doing. The increase in practice of self-control and self-regulation can help preschoolers identify strategies and tools to use instead of aggression that could eventually translate to other skills 
such as academic success (Jaekel, Eryigit-Madzwamuse, \& Wolke, 2016). This could be crucial for the transition to elementary school.

For the $40 \%$ that reported providing their child with family care or a babysitter/nanny, caregivers might be able to increase inhibitory control at home by practicing schedules that strategically ask children to complete tasks they do not like before completing a task they do like. Or, in these settings, children could be presented with self-control strategies and given repeated situations to practice those skills to increase overall inhibitory control. Programs such as Second Step provide curriculum for parents and teachers to increase social-emotional learning that could help children develop better self-control or self-regulation practices (Frey, Hirschstein, \& Guzzo, 2000). For example, Second Step introduces lessons and activities to help children understand what a normative display of aggression looks like and how to use skills to reduce aggressive outbursts. The more options children have for inhibiting aggression, the more likely they may use a strategy to avoid aggressive acts. By introducing self-regulation and self-control skills to bolster inhibitory control, children entering elementary school can make the transition with greater ease and focus on developing social-emotional and academic skills.

Although this study looked at 4-year-olds, our findings beg the question: Could age influence the relationship between low inhibitory control and high rates of aggression? Future directions for this study could look at areas of transitions, such as the change many students face from one class-a-day elementary school to seven-classes-a-day middle school. Furthermore, there are many age-related transitions that would be interesting to look at to see if the relationship between inhibitory control and aggression are influenced by age.

Moreover, as stated earlier, inhibitory control is only newly formed in 4-year-old children. Though we did find a high amount of low inhibitory control, it is expected that as 
children get older and are exposed to more situations and people where they have to practice inhibitory control that the number of children reporting low inhibitory control will reduce. Furthermore, I expect the relationship between inhibitory control and aggression to only further be pronounced with a few more years of development. This could become further important when looking at older children and adolescents and aggression. If children are not given proper practice for regulation and inhibitory control, the pull towards aggression might be more pronounced, and every choice to use aggression over another strategy could further push a child towards adapting a low inhibitory control mindset.

With prior studies only finding reactive aggression in kindergarten like Dodge et al.'s (1997) study looking at kindergartener's reactive and proactive aggression, a need for clarity comes. Was the significance revealed in the present study finding reactive and proactive regression in a 4-year-old sample purely from a difference in questionnaire or could the transition to kindergarten influence the amount of reactive and proactive aggression noted? In addition, it has been stated frequently here that gender differences in reactive and proactive aggression are mainly seen in adolescence since no significant differences were found here but were significant in Lozier et al.'s (2014) study with adolescent participants.

Additionally, the temperament dimension of high shyness and the interaction between gender and shyness and gender and inhibitory control did not yield any significant results. Future studies should look at gender interactions and temperamental shyness more in order to better understand the relationship between gender and temperament and its effect on aggression. Our finding that shyness was not a significant predictor of either reactive or proactive aggression was an interesting discovery considering many of the past studies sited here demonstrate a possible connection (Chang et al., 2005; Crozier \& Hostettler, 2003; Evans, 1987). For the most part, 
studies that try to connect shyness and aggression using temperament solely focus on other forms of aggression such as physical aggression (Brendgen et al., 2001; Dane \& Marini, 2014). Little of the research connecting shyness with aggression has focused specifically on reactive and proactive aggression. Furthermore, many aggression studies use clinical methods and samples for assessing aggression (Card \& Little, 2006), which could in turn cloud results linking shyness with aggression in community samples.

Possible limitations for this study could be that parent gender was not included on our demographics list. Olino et al. (2013) found that fathers reported boys demonstrated more sociability than girls. This finding could have serious implications for the level of shyness reported in boys versus girls in the current study. Furthermore, if parents are unconsciously reporting socialization differences between genders, then the same might be happening when reporting child's aggression. Additionally, when reporting on the CBQ, gender differences in the reports on extraversion and neuroticism are seen for female reporters across 37 nations (Lynn \& Martin, 1997). Yet Costa, Terracciano and McCrae (2001) reported that gender differences in reporting temperament are relatively small within genders and across nations. Understanding the difference in maternal versus paternal reporting could help even more when looking at the relationship between gender, temperament, and aggression.

Furthermore, the present study was majority White with $80 \%$ identifying with this racial group. Some studies have noted differences in race and ethnicity as accounting for variance in aggression and social acceptance in a longitudinal sample of 11-year-old boys (Lochman \& Wayland, 1994). Yet other studies have found few racial differences. For instance, Sagar and Schofield's (1980) study found evidence that White $6^{\text {th }}$ grade children were more likely than Black students in the same grade to read threats as "ambiguously aggressive behavior" but only 
when they believed the perpetrator of aggression to be stronger than the recipient. Racial differences in personality and behavior have been noted as early as lower elementary school (Gillum, Gomez-Marin, Prineas, 1984).

In conclusion, the current findings provide an analysis of two specific dimensions of temperament and two subtypes of aggression during the preschool years. The key finding in this study was that low inhibitory control is related to reactive and proactive aggression at 4 years of age. A child with low inhibitory control may have a harder time inhibiting aggressive acts associated with reactive and proactive aggression. Specifically, for reactive aggression, a child with low inhibitory control is less likely to inhibit aggressive responses or approaches, which could possibly make them adapt a hostile attribution bias leading to increased reactive aggression. Or, for proactive aggression, a child with low inhibition might be unable to suppress their need for stealing other children's toys when they really want to play with them. A child demonstrating low inhibitory control here exhibits low self-control by giving into their needs and using aggression to do so. By increasing behavioral interventions that focus on the establishment and growth of self-control and self-regulation at 4-years-old, children may be better prepared to handle everyday interactions and the transition to elementary school. 


\section{REFERENCES}

Bandura, A. (1973). Aggression: A social learning analysis. Englewood Cliffs, NJ: PrenticeHall.

Blair, R. J., (2008). Fine cuts of empathy and amygdala: Dissociable deficits in psychopathy and autism. The Quarterly Journal of Experimental Psychopathy, 61, 157-170.

Bohlin, G., Hagekull, B., \& Anderson, K. (2005). Behavioral inhibition as a precursor of peer social competence in early school age: The interplay with attachment and nonparental care. Merrill-Palmer Quarterly, 51, 1-19. https://www.jstor.org/stable/23096047

Brendgen, M., Vitaro, F., Tremblay, R. E., \& Lavoie, F. (2001). Reactive and proactive aggression: Predictions to physical violence in different contexts and moderating effects of parental monitoring and caregiving behavior. Journal of Abnormal Child Psychology, 29, 293-304.

Buhs, E. S., Rudasill, K. M., Kalutskaya, I. N., \& Griese, E. R. (2015). Shyness and engagement: Contributions of peer rejection and teacher sensitivity. Early Childhood Research Quarterly, 30, 12-19. http://dx.doi.org/10.1016/j.ecresq.2014.07.010

Buss, A. H., \& Plomin, R. (1975). A temperament theory of personality development. Oxford, UK: Wiley-Interscience.

Camodeca, M., Goossens, F. A., Terwogt, M. M., \& Schuengel, C. (2002). Bullying and victimization among school-age children: Stability and links to proactive and reactive aggression. Social Development, 11, 332-345.

Card, N. A., \& Little, T. D. (2006). Proactive and reactive aggression in childhood and adolescence: A meta-analysis of differential relations with psychosocial adjustment. International Journal of Behavioral Development, 30, 466-480. 
Carlson, S.M., \& Moses, L. J. (2001). Individual difference in inhibitory control and children's theory of mind. Child Development, 72, 1032-1053.

Chang, L., Lei, L., Li, K. K., Liu, Guo, B., Wang., Y., \& Fung, K. Y. (2005). Peer acceptance and self-perceptions of verbal and behavioural aggression and social withdrawal. International Journal of Behavioral Development, 29, 48-57. http://www.tandf.co.uk/jounrals/pp/01650244.html

Cloninger, R., Przybeck, T. R., Svrakic, D. M., \& Wetzel, R. D. (1994). The temperament and character inventory (TCI): A guide to its development and use. Washington University, St. Louis, MO: Center for the Psychobiology of Personality.

Comings, D. E., Gade-Andavolu, R., Gonzalez, N., Wu, S., Muhleman, D., Blake, H., Mann, M.B., Dietz, G., Saucier, G., \& MacMurray, J. P. (2001). A multivariate analysis of 59 candidate genes in personality traits: the temperament and character inventory. Clinical Genetics, 58, 375-385.

Connor, D. F., Stringard, R. J., Anderson, J. J., \& Melloni Jr., R. H. (2003). Gender differences in reactive and proactive aggression. Child Psychiatry and Human Development, 33, 279294.

Coplan, R. J., \& Prakash, K. (2003). Spending time with teacher: Characteristics of preschoolers who frequently elicit versus initiate interactions with teachers. Early Childhood Research Quarterly, 18, 143-158.

Coplan, R. J., Findlay, L. C., \& Nelson, L. J. (2004). Characteristics of preschoolers with lower perceived competence. Journal of Abnormal Child Psychology, 32, 399-408. 
Coplan, R. J., \& Armer, M. (2007). A “Multitude” of solitude: A closer look at social withdrawal and nonsocial play in early childhood. Child Development Perspectives, 1 , 26-32.

Costa, P.T, Terracciano, A., \& McCrae, R.R. (2001). Gender differences in personality traits across cultures: robust and surprising findings. Journal of Personality and Social Psychology, 81, 322-331.

Crick, N. R., \& Grotpeter, J. K. (1995). Relational aggression, gender, and social-psychological adjustment. Child Development, 66, 710-722.

Crick, N. R., Casas, J. F., \& Mosher, M. (1997). Relational and overt aggression in preschool. Psychology Faculty Publications, 88, 570-588. http://digitalcommons.unomaha.edu/psychfacpub/88

Crozier WR, Hostettler K. 2003. The influence of shyness on children's test performance. Br. J. Educ. Psychol. 73:317-28

Dadds, M. R., \& Salmon, K. (2003). Punishment insensitivity and parenting: Temperament and learning as interacting risks for antisocial behavior. Clinical Child and Family Psychology Review, 6, 69-86.

Dane, A. V., \& Marini, Z. A. (2014). Overt and relational forms of reactive aggression in adolescents: Relations with temperamental reactivity and self-regulation. Personality and Individual Difference, 60, 60-66. https://doi.org/10.1016/j.paid.2013.12.021

Denson, T.F., DeWall, N., \& Finkel, E.J. (2012). Self-control and aggression. SAGE Journals, $21,20-25$

Diamond, S. (1957). Personality and temperament. Oxford, UK: Harper \& Brothers. 
Dodge, K. A. \& Coie, J. D. (1987). Social-information-processing factors in reactive and proactive aggression in children's peer groups. Aggression and Misbehavior, 53, 11461158.

Dodge, K. A., Coie, J. D., Pettit, G. S., \& Price, J. M. (1990). Peer status and aggression in boys' groups: Developmental and contextual analyses. Child Development, 61, 1289-1309.

Dodge, K. A., \& Frame, C. L. (1982). Social cognitive biases and deficits in aggressive boys. Child Development, 53, 620-635.

Dodge, K. A., Harnish, J. D., Lochman, J. E., Baters, J. E., \& Pettit, G. S. (1997). Reactive and proactive aggression in school children and psychiatrically impaired chronically assaultive youth. Journal of Abnormal Psychology, 106, 37-51.

Doey, L., Coplan, R. J., \& Kingsbury, M. (2014). Bashful boys and coy girls: A review of gender differences in childhood shyness. Sex Roles, 70, 255-266.

Driscoll, H., Zinkivskay, A., Evans, K., \& Campbell, A. (2006). Gender differences in social representations of aggression: The phenomenological experiences of differences in inhibitory control? British Journal of Psychology, 97, 139-153.

Eisenberg, N., Fabes, R. A., \& Murphy, B. C. (1995). Relation of shyness and low sociability to regulation and emotionality. Journal of Personality and Social Psychology, 68, 305-517.

Else-Quest, N. M., Hyde, J. S., Goldsmith, H. H., \& Van Hulle, C. A. (2006). Gender differences in temperament: A meta-analysis. Psychological Bulletin, 132, 33-72.

Evans, M. A. (1993). Communicative competence as a dimension of shyness. In K. H. Rubin \& J. B. Asendorpf (Eds.), Social withdrawal, inhibition and shyness in childhood (pp. 189212). Hillsdale, NJ: Erlbaum 
Frey, K.S., Hirschstein, M.K., \& Guzzo, B.A. (2000). Second Step: Preventing aggression by promoting social competence. Journal of Emotional \& Behavioral Disorders, 8, 102-113.

Fox, N. A, \& Davidson, R. J. (1988). Patterns of brain electrical activity during facial signs of emotion in 10-month-old infants. Developmental Psychology, 24, 230-236.

Garofalo, C. \& Velotti, P. (2017). Negative emotionality and aggression in violent offenders: The moderating role of emotion dysregulation. Journal of Criminal Justice, 51, 9-16.

Gillum, R.F., Gomez-Martin, O., \& Prineas, R.J. (1984). Racial differences in personality behavior, and family environment in minneapolis school children. Journal of National Medical Association, 76, 1097-1105.

Goldsmith, H., Buss, A. H., Plomin, R., Rothbart, M. K., Thomas, A., Chess, S., Hinde, R. A., \& McCall, R. B. (1987). Roundtable: What is temperament? Four approaches. Child Development, 58, 505-529. https://www.jstor.org/stable/1130527

Harris, M.B. (1992). Sex, race, and experiences of aggression. Aggressive Behavior, 18.

Hart, C. H., Yang, C., Nelson, L. J., Robinson, C. C., Olsen, J. A., Nelson, D. A., Porter, C. L., Jin, S., Olsen, S. F., \& Wu, P. (2000). Peer acceptance in early childhood and subtypes of socially withdrawn behaviour in China, Russia, and the United States. International Journal of Behavioral Development, 24, 73-81. http://www.tandf.co.uk/journals/pp/01650254.html

Hatfield, J. \& Dula, C.S. (2014). Impulsivity and physical aggression: Examining the moderating role of anxiety. The American Journal of Psychology, 127, 233-243.

Hay, D. F., Nash, A., Caplan, M., Swartzentruber, J., Ishikawa, F., \& Vespo J. E. (2011). The emergence of gender differences in physical aggression in the context of conflict between young peers. British Journal of Developmental Psychology, 29, 158-175. 
Hirshfeld-Baker, D. R., Biederman, J., Henin, A., Faraone, S. V., Davis, S., Harrington, K., \& Rosenabum, J. F. (2007). Specific predictor of middle childhood social anxiety: A five-year follow-up. Journal of Developmental \& Behavioral Pediatrics, 28, 225-233.

Hubbard, J. A., McAuliffe, M. D., Morrow, M. T., \& Romano, L.J. (2010). Reactive and proactive aggression in childhood and adolescence: Precursors, outcomes, processes, experiences, and measurement. Journal of Personality,78. https://doi.org/10.1111/j.1467-6494.2009.00610.x

Kagan, J. (1998). Biology and the child. In W. Damon \& N. Eisenberg (Ed.), Handbook of child psychology: Social, emotional, and personality development (pp. 177-235). Hoboken, NJ: Wiley.

Kagan, J., \& Snidman, N. (1999). Early childhood predictors of adult anxiety disorders. Biological Psychiatry, 46, 1536-1541. https://doi.org/10.1016/S0006-3223(99)00137-7

Kendall, P. C., Hedtke, K. A., \& Aschenbrand, S. G. (2006). Anxiety disorders. In D. A. Wolfe \& E. J. Mash (Eds.), Behavioral and emotional disorders in adolescents: Nature, assessment, and treatment (pp. 259-299). New York, NY: Guilford Publications.

Kessler, R. C., Berglund, P., Demler, O., Jin, R., Merikangas, K. R., \& Walters, E. E. (2005). Lifetime prevalence and age-of-onset distributions of DSM-IV disorders in the national comorbidity survey replication. Archives of General Psychiatry, 62, 593-602.

Kimonis, E. R., Frick, P. J., Boris, N. W., Smyke, A. T., Cornell, A. H., Farrell, J. M., \& Zeanah, C. H. (2006). Callous-unemotional features, behavioral inhibition and parenting: independent predictors of aggression in a high-risk preschool sample. Journal of Child and Family Studies, 15, 745-756. 
Kochanska, G., DeVet, K. Goldman, M. Murray, K., \& Putnam, S. P. (1994). Maternal reports of conscience development and temperament in young children. Child Development, 65, 852-868. https://www.jstor.org/stable/1131423

Kochanska, G., Murray, K. T., \& Harlan, E. T. (2000). Effortful control in early childhood: Continuity and change, antecedents, and implications for social development. Developmental Psychology, 36. 220-232.

Howart, E. (1988). Mood differences between the four Galen personality types: choleric, sanguine, phlegmatic, melancholic. Personality and Individual Differences, 9, 173-175. https://doi.org/10.1016/0191-8869(88)90044-X

Lerner, J. V., Lerner, R. M., \& Zabski, S. (1985). Temperament and elementary school children's actual and rated academic performance: A test of a "Goodness-of-Fit" model. Journal of Child Psychology and Psychiatry, 26, 177-188. https://doi.org/10.1111/j.14697610.1985.tb01633.x

Lesch, K. P., \& Merschdorf, U. (2000). Impulsivity, aggression, and serotonin: A molecular psychobiological perspective. Behavioral Sciences and the Law, 18, 581-604.

Loeber, R., \& Dishion, T. (1983). Early predictors of male delinquency: A review. Psychological Bulletin, 94, 68-99.

Loeber, R., \& Farrington, D. P. (2000). Young children who commit crime: Epidemiology, developmental origins, risk factors, early interventions, and policy implications. Development and Psychopathology, 12, 737-762.

Lochman, J.E., \& Wayland, K.K. (1994). Aggression, social acceptance, and race as predictors of negative adolescent outcomes. Journal of the American Academy of Child and Adolescent Psychiatry, 33, 1026-1035. 
Lozier, L. M., Cardinale, E. M., VanMeter, J. W., \& Marsh, A. A. (2014). Mediation of the relationship between callous-unemotional traits and proactive aggression by amygdala response to fear amount children with conduct problems. Journal of American Medical Association Psychiatry, 71, 637-636.

Lynn, R., \& Martin, T. (1997). Gender differences in extraversion, neuroticism, and psychoticism in 37 nations. Journal of Social Psychology, 137, 369-373.

Martin, R. P., Weisenbaker, J., \& Huttunen, M. (1994). Review of factor analytic studies of temperament measures based on Thomas-chess structural model: Implications for the big five. In C. F. Halverson, Jr., G. A. Kohnstamm, \& R. P. Martin (Eds.), The developing structure of temperament and personality from infancy to adulthood (pp. 157-172). Hillsdale, NJ: Erlbaum.

Matthies, S., Rusch, N., Weber, M., Lieb, K., Philipsen, A., Tuescher, O., Ebert, D., Hennig, J., \& Tebartz Van Elst, L. (2012). Small amygdala- high aggression? The role of the amygdala in modulating aggression in healthy subjects. The World Journal of Biological Psychiatry, 13, 75-81.

McClowry, S. G., Rodriguez, E. T., Tamis-LeMonda, C. S., Spellmann, M. E., Carlson, A., \& Snow, D. L. (2013). Teacher/ student interactions and classroom behavior: The role of student temperament and gender. Journal of Research in Childhood Education, 27, 283301.

Moffitt, T. E., Caspi, A., Harrington, H., \& Milne, B. J. (2002). Males on the life-coursepersistent and adolescence-limited antisocial pathways: Follow-up at age 26 years. Development and Psychopathology, 14, 179-207. 
Murray, K. T., \& Kochanska, G. (2002). Effortful control: Factor structure and relation to externalizing and internalizing behaviors. Journal of Abnormal Child Psychology, 30, 503-514.

Olino, T. M., Durbin, C.E., Klein, D. N., Hayde, E. P., Dyson, M.W. (2013). Gender differences in young children's temperament traits: Comparisons across observational and parentreport methods. Journal of Personality, 81, 119-129.

Olweus, D. (1981). Continuity in aggressive and withdrawn, inhibited behavior patterns. Psychiatry and Social Science, 1, 141-159

Parke, R. D., \& Slaby, R. G. (1983). The development of aggression. In P. H. Mussen \& E. M. Hetherington (Eds.), Handbook of child psychology: Vol. 4. Socialization, personality, and social development (pp. 547-641). New York, NY: Wiley

Pfeifer, M., Goldsmith, H. H., Davidson, R. J., \& Rickman, M. (2002) Continuity and change in inhibited and uninhibited children. Child Development, 73, 1474-1485.

Polman, H., Castro, B.O., Koops, W., Boxtel, H. W., \& Merk, W. W. (2007). A meta-analysis of the distinction between reactive and proactive aggression in children and adolescents. Journal of Abnormal Child Psychology, 35, 522-535.

Poulin, F., \& Boivin, M. (2000). Reactive and proactive aggression: Evidence of a two-factor model. Psychological Assessment, 12, 115-122.

Price, J. L. (2007). Definition of the orbital cortex in relation to specific connections with limbic and visceral structures and other cortical regions. Annals of the New York Academy of Sciences, 112, 54-71. 
Prior, M., Smart, D., Sanson, A., \& Oberklaid, F. (2000). Does shy-inhibited temperament in childhood lead to anxiety problems in adolescence? Journal of the American Academy of Child \& Adolescent Psychiatry, 39, 461-468. https://doi.org/10.1097/00004583200004000-00015

Putnam, S. P., \& Rothbart, M. K. (2006). Development of short and very short forms of the children's behavior questionnaire. Journal of Personality Assessment, 87, 102-112.

Raaijmakers, M.A.J., Smidts, D. P., Sergeant, J.A, Maassen, G.H., Posthumus, J.A., Van Engeland, H., Matthys, W. (2000) Executive functions in preschool children with aggressive behavior: impairments in inhibitory control. Journal of Abnormal Child Psychology, 36, 1097-107.

Raine, A., Dodge, K., Loeber, R., Gatzke-Kopp, L., Lynam, D., Reynolds, C., StouthamerLoeber, M., \& Liu, J. (2006). The reactive-proactive aggression questionnaire: Differential correlates of reactive and proactive aggression in adolescent boys. Aggressive Behaviors, 32, 159-171.

Rettew, D. C., \& McKee, L. (2005). Temperament and its role in developmental psychopathology. Harvard Review of Psychiatry, 13, 14-27.

Rettew, D. (2013). Child temperament: New thinking about the boundary between traits and illness. New York, NY: Norton.

Reznick, J. S., Kagan, J., Snidman, N., Gersten, M., Baak, K., \& Rosenberg, A. (1986). Inhibited and uninhibited children: A follow-up study. Child Development, 57, 660-680.

Rimm-Kaufman, S. E., \& Kagan, J. (2005). Infant predictors of kindergarten behavior: The contribution of inhibited and uninhibited temperament types. Behavioral Disorders, 30, $331-347$. 
Rothbart, M. K., Ahadi, S. A., \& Hershey, K. L. (1994). Temperament and social behavior childhood. Merrill-Palmer Quarterly, 40, 21-39. https://www.jstor.org/stable/23087906

Rothbart, M. K., Ahadi, S.A., \& Evans, D. E. (2000). Temperament and personality: Origins and outcomes. Journal of Personality and Social Psychology, 78, 122-135.

Rothbart, M. K., Ahadi, S. A., Hershey, K. L., \& Fisher, P. (2001). Investigations of temperament at three to seven years: The children's behavior questionnaire. Child Development, 72, 1394-1408.

Rothbart, M. K., Ellis, L. K., Rueda, M. R. \& Posner, M. I. (2003). Developing mechanisms of temperamental effortful control. Journal of Personality, 71, 1113-1144.

Rothbart, M. K., Sheese, B. E., \& Posner, M. I. (2007) Executive attention and effortful control: Linking temperament, brain networks, and genes. Child Development Perspectives, 1 https://doi.org/10.1111/j.1750-8606.2007.00002.x

Rothbart, M. K. (2007) Temperament, development, and personality. Current Directions in Psychological Science, 16, 207- 212.

Rubin, K. H., \& Asendorpf, J. B. (1993). Social withdrawal, inhibition, and shyness in childhood. Hillsdale, NJ: Erlbaum.

Sagar, H.A., \& Schofield, J.W. (1980). Racial and behavioral cues in black and white children's perceptions of ambiguously aggressive acts. Journal of Personality and Social Psychology, 39, 590-598.

Sanson, A. \& Rothbart, M. K. (1995). Child temperament and parenting. In M. Bornstein (Ed.), Handbook of parenting. Applied and Practical Parenting, 4, pp 299-321. Hillsdale, NJ: Erlbaum. 
Sanson, A., Hemphill, S. A., \& Smart, D. (2004) Connections between temperament and social development: A review. Social Development, 13, 142-170. https://doi.org/10.1046/j.1467-9507.2004.00261.x

Schwartz, C. E., Snidman, N., \& Kagan, J. (1999). Adolescent social anxiety as an outcome of inhibited temperament in childhood. Journal of the American Academy of Child \& Adolescence Psychiatry, 38, 1008-1015

Schwartz, C. E., Wright, C. I., Shin, L. M., Kagan, J., \& Rauch, S. L. (2003). Inhibited and uninhibited infants "grown up": Adult amygdalar response to novelty. Science Magazine, 300, 1952-1953.

Schwartz, C. E., Kunwar, P. S., Greve, D. N., Moran, L. R., Viner, J. C., Covino, J. M., Kagan, J., Stewart, E., Snidman, N. C., Vangel, M. G., \& Wallace, S. R. (2010). Structural differences in adult orbital and ventromedial prefrontal cortex predicted by infant temperament at 4 months of age. Archives of General Psychiatry, 67, 78- 84.

Seguin, J.R., \& Zealzo, P.D. (2005). Executive function in early physical aggression. In R.E. Tremblay, W.W. Hartup, \& J. Archer (Eds.) Developmental origins of aggression (pp. 307-329). New York: Guilford.

Theall-Honey, L.A., \& Schmidt, L.A., (2006). Do temperamentally shy children process emotion differently than nonshy children? Behavioral, psychophysiological, and gender differences in reticent preschoolers. Developmental Psychobiology, 48, 187-196.

Thomas, A., Chess, S., Birch, H. G., Hertzig, M. E., \& Korn, S. (1963). Behavioral individuality in early childhood. New York, NY: New York University Press.

Thomas, A., Chess, S., \& Birch, H. G. (1968). Temperament and behavior disorders in children. New York: New York University Press. 
Thomas, A., \& Chess, S. (1986). The New York Longitudinal Study: From infancy to early adult life. In R. Plomin \& J. Dunn (Eds.), The study of temperament: Changes, continuities, and challenges (pp. 39-52). Hillsdale, NJ: Erlbaum.

Thomas, D. E., Bierman, K. L., \& Powers, C. J. (2011). The influence of classroom aggression and classroom climate on aggressive-disruptive behavior. Child Development, 82, 751757.

Tremblay, R. E., Nagin, D.S., Séguin, J. R., Zoccolillo, M., Zelazo, P. D., Boivin, M., Pérusse, D., \& Japel, C. (2004). Physical aggression during early childhood: Trajectories and predictors. Pediatrics, 114, 43-50. 